\title{
農薬製荗のFT-IR/ATRスペクトルによる異同識別
}

\author{
石原悟*, 豊 留夏 紀 \\ 農林水産消費安全技術センター農薬検査部
}

（2011年7月29日受付，2012年2月26日受理）

\section{Discriminant analysis of pesticide formulations by FT-IR/ATR spectroscopy}

\author{
Satoru IshiHARA* and Natsuki Toyodome \\ Incorporated Administrative Agency Food and Agricultural Materials Inspection Center, \\ Agricultural Chemicals Inspection Station, \\ 2-772 Suzuki-cho, Kodaira-shi, Tokyo 187-0011, Japan
}

\begin{abstract}
To ensure the safety of the environment and human health, the manufacture of pesticide formulations must be in accord with registered formula components. The Agricultural Chemicals Inspection Station therefore regularly inspects the formula components of commercial samples. The purpose of this paper is to introduce a simple method using Fourier transform infrared attenuated total reflection (FT-IR/ATR) spectroscopy for the identification of the formula components of registered and commercial samples. The FT-IR/ATR technique is fast and relatively easy to use; it requires no sample pretreatment for most solid and liquid pesticide formulations, with the exception of some ready-touse liquid formulations. The transmittance spectrum $\left(4,000-650 \mathrm{~cm}^{-1}\right)$ is useful for inspection. We used three evaluation methods to identify the components of the formula: overlap of two spectra, calculation of the purity index, and use of principal component analysis (PCA). ㅇ Pesticide Science Society of Japan
\end{abstract}

Keywords: FT-IR/ATR, mid-infrared spectrum, purity index, principal component analysis (PCA).

\section{は じめに}

農薬製剂は農薬として主な効果を示す有効成分と補助成分 とで構成されており，登録申請時には製剂毎に詳細な処方と 有効成分を含め全ての成分を分析する方法の報告が実施され ている ${ }^{1)}$. 登録された農薬製剂は，申請時の処方で製造され た製剤を用いて毒性，薬効・薬害の有無など各種安全性と効 果が確認されているため, これらを担保する観点から原則的

* $=187-0011$ 東京都小平市鈴木町 2-772

E-mail: satoru_ishihara@acis.famic.go.jp

Published online April 29, 2012

(C) Pesticide Science Society of Japan
には登録時の処方を変更することは認められておらず，やむ を得ず変更する場合は, 必要に応じ追加の試験成績の提出が 求められている ${ }^{2)}$. 諸外国においても, 農薬製剤の処方変更 については, 軽微な変更を除き再評価が必要とされてい $る^{3,4)}$.

農林水産消費安全技術センター農薬検査部では, 集取品 （農薬製剂製造工場の立入検査に伴い集取した農薬）につい て処方検查（申請処方と農薬製造工場で入手した処方の異同 識別の検查）を行っている. 処方検查では各補助成分につい て個別に分析（定性抢よび定量）し，処方の異同識別を行う ことが望ましいが, 多大な労力と分析コストを必要とするた め, 通常は申請時の処方と製造現場で確認した処方の比較に よる検査で対応している. 
これまで当部（前身の農薬検査所）では，簡易で科学的な 処方検查の手法として, 核磁気共鳴装置（NMR）の利用を 検討し，処方検查への実用性を示した ${ }^{5-7)}$. しかし，NMR は総所有コストが高額なため, 分析コストが高額となる短所 があることから, 簡易かつ低分析コストで科学的な処方検查 の手法開発が急務であった.

IR（赤外分光法）は振動分光法の一つで, 固体, 液体, 気 体などさまざまな状態にある試料に適用できる。また，測定 か簡易で試料を損傷することなく非破壊分析が可能なため, さまざまな分野において品質管理，異同識別，分類などに利 用されている ${ }^{8-14)}$. IR の中でも FT-IR（フーリ工変換赤外分 光法）は，1）分解能が高い，2）測定時間が短い，3）総所 有コストが低い，など優れた特徴を有していることから，医 薬品の有効成分の異同識別法 ${ }^{15)}$ としても採用されている FT-IRに着目し，同法を用いた農薬製剂処方の異同識別手法 の開発を進めた ${ }^{16-18)}$ 。その結果，処方検査で実用が期待さ れる結果が得られたので報告する。

\section{1. 農薬製剂の赤外スペクトルの測定手法の検討}

農薬製剂（気体の製剤を除く）の処方検査に用いる赤外ス ペクトルの測定手法として, FT-IRの透過法と全反射法 （ATR: Attenuated Total Reflection）を，測定波数領域とし て, 中赤外 $\left(4,000-400 \mathrm{~cm}^{-1}\right.$, 対応可能波数範囲が $7,800-$ $240 \mathrm{~cm}^{-1}$ の DLATGS 検出器を使用), と近赤外 (12,500$4,000 \mathrm{~cm}^{-1}$, 対応可能波数範囲 が $12,500-3,800 \mathrm{~cm}^{-1}$ の InGaAs 検出器を使用）の領域を検討した．FT-IRの測定は， IRPrestige-21（Shimadzu Co. Kyoto, Japan）を用い，ATR法 では 1 回反射 ATR装置（DuraSampl IRII ${ }^{\mathrm{TM}}$, SensIR Technologies, Danbury, CT, USA）を接続して測定した。透過法によ る澄明液体製剂の測定では，光路長 $2 \mathrm{~mm}$ の石英セルを用い た．ATR法では，試料をダイヤモンド/セレン化亜鉛結晶 (入射角度約 45 度, 有効面積直径 $1 \mathrm{~mm}$, 測定可能な波数領 域 20,000-650 $\left.\mathrm{cm}^{-1}\right)$ 上に置き，測定試料が固体の場合，直 径 $3 \mathrm{~mm}$ の金属棒を用いて押しつけ，密着した状態で測定し た. 測定条件は，透過法とATR法ともに，積算回数 40 回， 分解能 $4 \mathrm{~cm}^{-1}$ とした.

検討の結果，農薬製剂の形状は，粉末，粒状，液体，ペー スト状など多様であることから，処方検査での赤外スペクト ルの測定には，さまざまな形状の試料の測定が可能である ATR法が透過法と比較して有用であることが示された ${ }^{16-18)}$. また，ATR法は希釈等試料の前処理をほとんど必要とせず に農薬製剤の赤外スペクトルの測定が可能であったことか ら，より簡易な異同識別手法の確立が期待された。

ATR法による測定では近赤外領域 $\left(7,800-4,000 \mathrm{~cm}^{-1}\right)$ に 波形比較が可能な吸収ピークは検出されなかった（図1). 乳剤やフロアブルなどの透過法による測定で検出される近赤 外領域の吸収ピークがATR法による測定で検出されなかっ

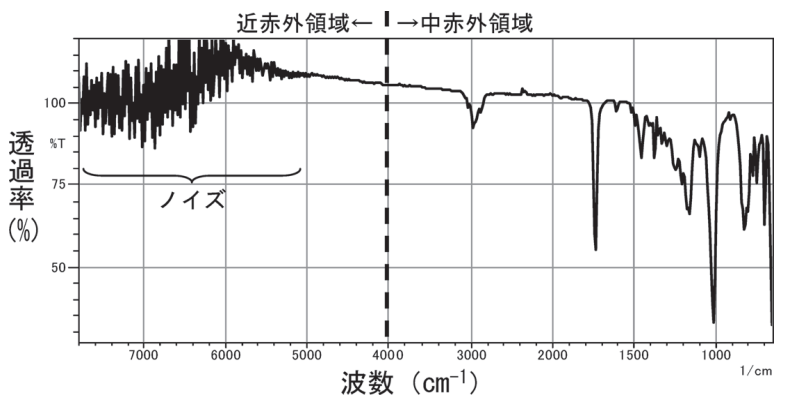

図1.ATR法で測定した乳剂*の赤外スペクトル *マラソン乳剂

た要因として, 光路長が $2 \mathrm{~mm}$ のルを使用して測定した透 過法と比較し, ATR法では赤外線の染み込みの深さが $1 \mu \mathrm{m}$ と浅いため, 低感度な測定法であることが考えられた。これ までATR法で測定した農薬製剤試料に関して近赤外領域 (7,800-4,000 $\left.\mathrm{cm}^{-1}\right)$ に処方検查に有用な吸収ピークは検出 されなかったこと，また，今回の測定条件では，同領域 $\left(>5,000 \mathrm{~cm}^{-1}\right)$ に強いノイズが確認されたことから，ATR 法による測定結果を処方検查に利用する場合, 波形比較に用 いる波数領域は中赤外領域 $\left(4,000-400 \mathrm{~cm}^{-1}\right)$ が適当である と考えられた。なお，今回の検討におけるATRアクセサリ と検出器の組み合わせでは測定可能波数領域が $7,800-$ $650 \mathrm{~cm}^{-1}$ であったことから, 測定波数領域は 4,000-650 $\mathrm{cm}^{-1}$ に設定した。

\subsection{ATR法による農薬製剤の測定}

ATR法による測定では，ATRエレメントと呼ばれる結晶 の表面に試料を接触させて試料表面のわずかな厚み部分の測 定を行っている. 試料とATRエレメントとの接触の度合い （密着度）が測定結果を左右する（密着度が高いとピーク強 度が強くなる）ため, 高い再現性で赤外スペクトルを測定す るには, 試料とATRエレメントとの密着度に留意する必要 があった。測定試料が液体の場合, 試料とATRエレメント との密着度は測定ごとにばらつきが小さく，再現性の高い測 定が容易であった, 一方, 測定試料が固体の場合, 試料と ATRエレメントとの密着度が測定ごとにばらつくため, ATR装置に付属する加圧プレスで密着度を調整し, 測定毎 のスペクトル強度を一定にする必要があった。また，測定試 料が粒剂の場合, 試料の不均一性を解消するため, 試料を乳 鉢で粉砕する前処理が必要であった ${ }^{17)}$.

\section{2. 差スペクトルの利用}

水分子は赤外領域に極めて強い吸収があるため，水分を多 量に含有する製剂（フロアブル，液剤）のスペクトルは，水 のスペクトル（図2-A）とょく似ていた（図2-B）。通常これ らの製剂の水分以外の成分に帰属する吸収ピークは，水に帰 

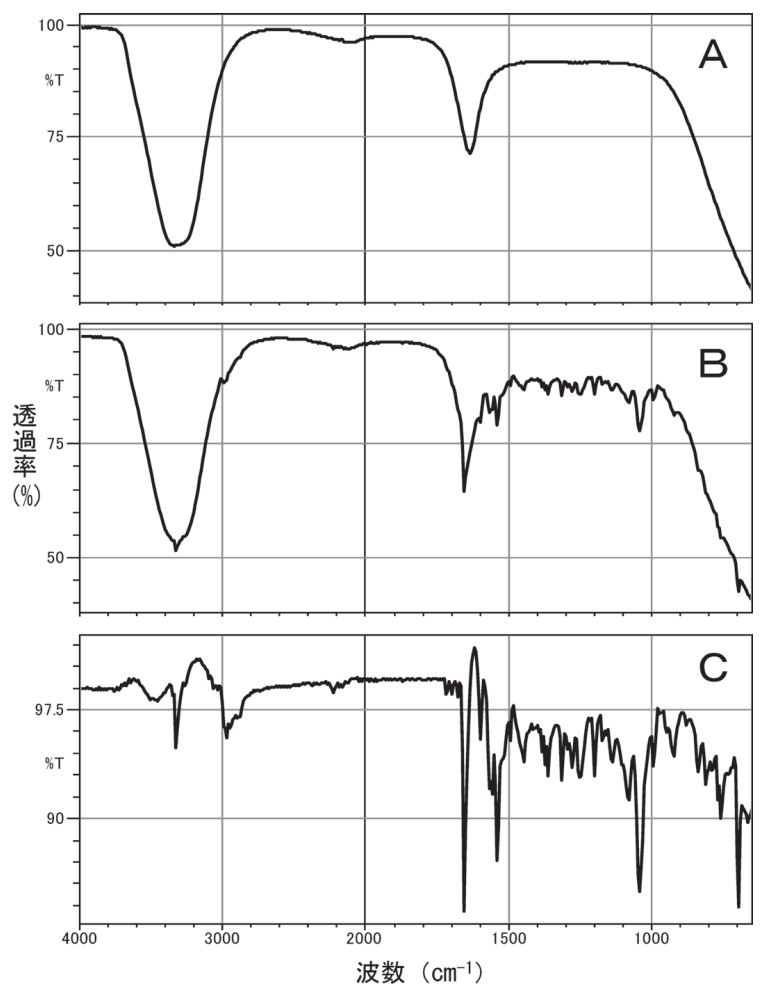

図2. ATR法で測定した水道水（A）および水和剤*（フロアブル） （B）の赤外スペクトルとその差スペクトル（C）

*ダイムロン・ピラクロニル・ブロモブチド・ベンスルフロンメチル 水和剂

属する吸収ピークと比較し, 微弱なピークであるため, 赤外 スペクトル波形（生データ）の比較から処方の異同識別を行 うことは困難であり，製剤の生データを処方検查に利用する ことは効率的でないと考えられた。そこで, ATR法による フロアブルおよび液剤の測定結果から水の吸収を差し引いた スペクトル（差スペクトル）の計算を行った．差スペクトル の計算は, 計測機器の制御ソフトウェア (IRsolution 1.40, Shimadzu Co. Kyoto, Japan）におけるスペクトル演算機能を 利用し, 演算に必要な係数は, 処理結果スペクトルを確認 し，ベースラインが水平になるよう調整して決定したにその 結果, 差スペクトルは生データと比較し, 製剤の水分以外の 成分特有のピークを鮮明に確認でき, スペクトル波形の比較 が容易になった（図2-C).

差スペクトルを利用することで, 水分を96\%含有する製 剂で, 微弱ながら異同識別に利用可能と考えられる水分以外 の成分特有のスペクトルを得ることができた，製剤構成成分 における赤外吸収の強弱にもよるが，これまでの測定結果で は，前処理を行わず赤外スペクトルを測定し評価する手法の 限界は，水分含量 $96 \%$ 程度であった。な扔，水分含有率が 極めて高い製剤（AL剂など）に関しては，前処理として製 剂中に含まれる一部の成分をジクロロメタン相に転溶・濃縮 した溶液（約 20 倍濃縮）を測定試料とすることで，ジクロ
ロメタン相に転溶される成分由来に限られるものの異同識別 に利用可能な製剤特有の赤外スペクトルの測定が可能であっ $た^{18)}$.

\section{2. 異同識別手法}

赤外スペクトル波形の比較を利用した処方の異同識別手法 として，1）スペクトルの重齐描き，2）一致度計算，3） PCA（主成分分析）の3つの手法について検討した.

\section{1.スペクトルの重ね描き}

見本品（農薬登録申請時に提出される製剤）の赤外スペク トルと同条件で測定し得られた集取品の赤外スペクトルを重 ねあわせることで, 検出されるピークの比較が可能であった （図 3-A). 本手法は簡易で有効な評価手法であるが，波形の 細かな異なりを評価することが困難であった。

\section{2. 一致度計算}

一致度計算は, 計測機器の制御ソフトウェア（IRsolution）に付属された機能を利用した。一致度（P; purity index）は赤外スペクトル間の一致の度合を表す係数で, 対象 となる2つの赤外スペクトルのすべての強度について計算さ れる最小二乗近似係数によって与えられ, 次の式により計算 されたものである.

$$
P=\frac{\sum_{i}^{n}\left(s_{i}-\bar{s}\right)\left(r_{i}-\bar{r}\right)}{\sqrt{\sum_{i}^{n}\left(s_{i}-\bar{s}\right)^{2} \sum_{i}^{n}\left(r_{i}-\bar{r}\right)^{2}}}
$$

$s_{i}=$ 同じ横軸值における強度值（試料）

$r_{i}=$ 同じ横軸值における強度值（見本品）

$n=$ スペクトル点数

一致度計算の結果得られる一致度および相関図（図3-B） は処方検查における異同識別の判定に有用であり, スペクト ルの重齐描きで識別し難い細かな波形の異なりを判別する有 効な評価手法であると考えられた。

\subsection{PCA（主成分分析）}

本検討で測定した赤外スペクトルは透過率と波数からなる 多変量情報であることから, 各製剤の赤外スペクトルを相互 に関連する情報と考え, 多変量解析を行うことで, 製剂処方 の同一性の確認が可能となると考えられた。このような化学 的データの統計学的解析手法はケモメトリックスと呼ばれ, 計算機の性能の向上とともに汎用性が高まり多様な分野での 利用が進んでいる ${ }^{19)}$. 本検討における PCA は, 市販のケモ メトリックス用ソフトウェア (Pirouette3.11, Infometrix Inc., Bothell, WA, USA.）を用い, ATR法により測定した波 

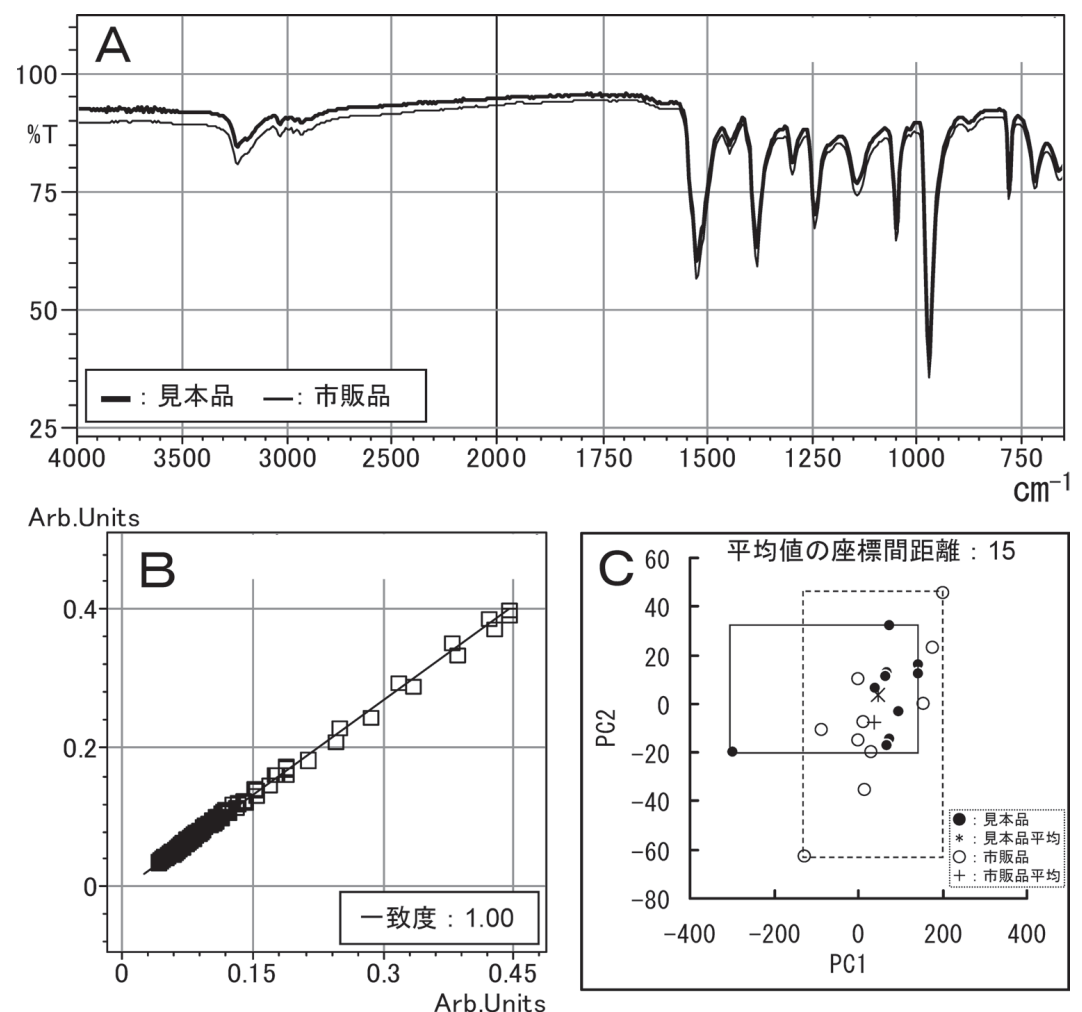

図3. 水和剤*の赤外スペクトル（見本品および市販品を各10回測定）について形状比較により処方の異同識別を行った結果 スペクトルの重齐描き (A)，一致度計算（B)，PCA（C)

*ポリカーバメート水和剤

数領域 $\left(4,000-650 \mathrm{~cm}^{-1}\right)$ の透過率もしくは差スペクトルの 同波数領域の透過率データをデータセットとして2次元に射 影し2次元散布図で解析を行う手法を検討した。なお，本検 討では, スペクトルデータの前処理および変換として，平均 化およびベースライン補正を行った。

2次元散布図から製剤処方の同一性を評価する指標として は，プロットされる座標領域の重なり具合や座標間距離の利 用が期待された（図3-C)。評価の指標とするにはさらなる 測定事例の集積に努める必要があるが，これまでの結果で は, 同一処方と考えられる製剤の解析結果で座標間の距離 （10 回測定の平均值）は液体製剤で 40 ，固形製剤で 150 を超 えることはなく，この数值を評価の一定の目安としている.

PCAで解析を行ったことで, 前述の重㸚描きや一致度計 算で検出が困難な赤外スペクトル波形の異なりが検出可能で あることから，処方検查における異同識別の手法として有用 であると考えられた。

PCAによる解析の異同識別能力の高さを示す一例として, MEP乳剂中のキシレンの異性体組成の識別について例示す る。キシレンは農薬製剂の補助成分として使用頻度の高い有 機溶媒であり，通常農薬製剤の製造には工業用のキシレンが 使用されている．異性体を含む工業用キシレンはオルトキシ レン,メタキシレン，パラキシレンおよびエチルベンゼンの
混合物として組成されており, 溶剤としての使用が多い分解 系キシレンは約 $40 \%$ のエチルベンゼンが含有されている ${ }^{20,21)}$. 原料によるエチルベンゼンの含有量の差異は大きいため, 製 剤中のエチルベンゼン含量は製品により異なる。図4は製造 ロットの異なる同一処方の $50 \% \mathrm{MEP}$ 乳剂 8 試料について FT-

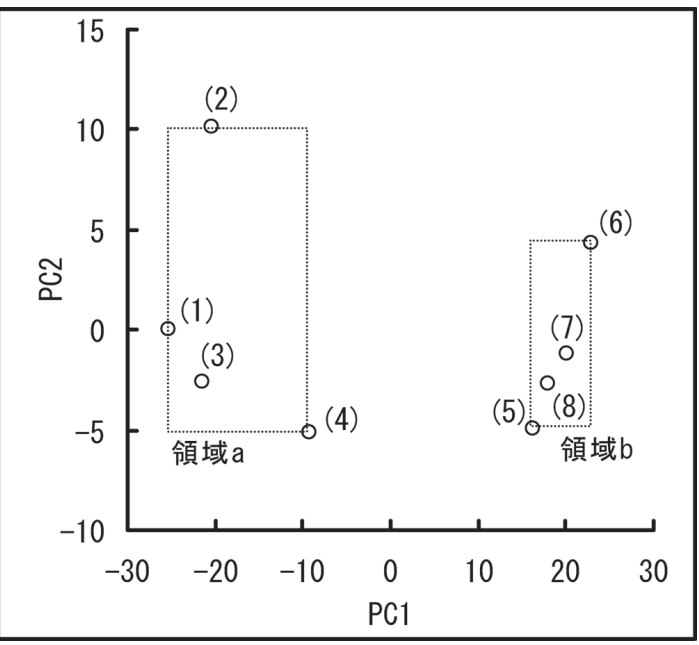

図4. MEP乳剂（8試料）の赤外スペクトルの測定值にPCAを施した 結果 括弧内の数值は試料番号を示す 


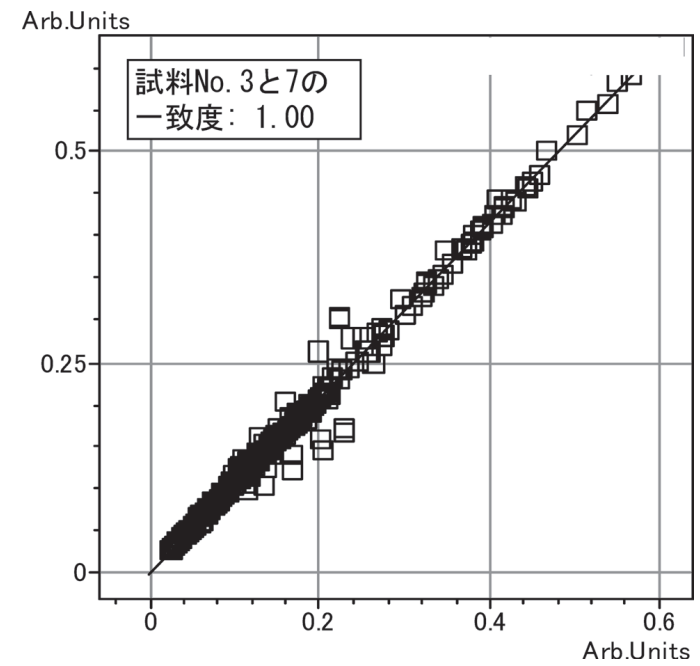

図 5. MEP乳剂（試料No. 3 と 7）の赤外スペクトルの一致度

IR/ATR法で測定した測定值（透過率，波数領域4,000$\left.650 \mathrm{~cm}^{-1}\right)$ を主成分分析で解析した結果である．同一処方の 製剤の測定結果であるが，散布図では2つの領域に分離しプ ロットされる結果が得られた。高速液体クロマトグラフによ り試料中のキシレンの異性体構成を明らかにしたところ, 領

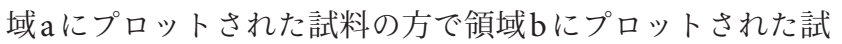
料に比べエチルベンゼンの含有率が低いことが明らかになっ $た^{16)}$. 補助成分として使用されているキシレン中の異性体 構成比の違いは, スペクトルの重齐描きや一致度計算（図5） から判別することは困難であり, PCAによる解析の異同識 別能力の高さを示す結果が得られた。

\section{3. 市販品の処方の異同識別}

市販の農薬製剤 8 剂を測定試料として, FT-IR/ATR法によ る処方検查の試験的運用を行った．測定した赤外スペクトル を前述の1-3）の方法で評価したところ，すべての製剤で提 出された見本品の測定結果と高い相同性を示し, 処方の変更 が疑われる事例は確認されなかった（表1）.

本検討で製剂処方の異同識別に利用した赤外スペクトル は，いずれも同じ測定機器で同時期に測定したものである. 今後の課題として, 本手法の汎用性の確認を行うとともに, スペクトルデータのデータベース化を進める必要があると考 えられた。

\section{おわりに}

FT-IR/ATR法を利用することで，簡易かつ低分析コスト で科学的な処方検查の手法を確立できた。検査結果の良否判 定には判別曲線や信頼区間など適正な統計的手法を選択する ことが望ましいが，農薬製剤を測定試料とする場合，集取す る試料数には限度があり, 通常の処方検查において統計的手 法を用い良否判定を下すことはできない，本検査結果だけで 処方の良否判定を下すことは望ましいことではなく, 赤外ス ペクトル波形の比較による処方検査はスクリーニング評価と 位置付け，さらなる検査（使用されている補助成分の定性・ 定量）の要・不要の判断への利用が期待される.

\section{謝 辞}

本研究の実施にあたり，クミアイ化学工業株式会社，住友 化学株式会社, 日産化学工業株式会社, 三井化学アグロ株式 会社より農薬補助成分の試料をご提供いただきました。この 場をお借りしてお礼申し上げます。

表 1. 赤外スペクトルの形状比較による処方検査の結果

\begin{tabular}{|c|c|c|c|c|}
\hline 試料番号 & 剂型 & 評価した赤外スペクトルの種類 & 一致度 & PCA 座標間距離* \\
\hline 1 & 粉剂 ${ }^{1)}$ & $\mathrm{ATR} \rightarrow$ 生データ & 1.00 & 40 \\
\hline 2 & 粒剂 ${ }^{2}$ & $\mathrm{ATR} \rightarrow$ 生データ & 1.00 & 132 \\
\hline 3 & 水和剂 ${ }^{3)}$ & $\mathrm{ATR} \rightarrow$ 生データ & 1.00 & 15 \\
\hline 4 & 水和剤（フロアブル） & $\mathrm{ATR} \rightarrow$ 差スペクトル & 0.99 & 14 \\
\hline 5 & 水和剤（フロアブル） & $\mathrm{ATR} \rightarrow$ 差スペクトル & 0.99 & 39 \\
\hline 6 & 液剂 ${ }^{6)}$ & 濃縮試料 $\rightarrow$ ATR $\rightarrow$ 生データ & 0.95 & 1 \\
\hline 7 & 乳剤7) & $\mathrm{ATR} \rightarrow$ 生データ & 1.00 & 9 \\
\hline 8 & 乳剂 ${ }^{8)}$ & $\mathrm{ATR} \rightarrow$ 生データ & 1.00 & 34 \\
\hline
\end{tabular}

1）イミノクタジン酢酸塩・フサライド粉剂，2）カフェンストロール・ダイムロン・ベンスルフロンメチル・ベンゾビシクロン粒剤，3）ポ リカーバメート水和剤，4）多イロン・ピラクロニル・ブロモブチド・ベンスルフロンメチル水和剤，5）テフリルトリオン・メフェナセッ ト水和剂，6）シフルトリン・ビテルタノール液剤，7）ジメテナミド乳剂，8）オキサジアゾン・ブタクロール乳剤

*主成分得点の平均值の 2 次元散布図上における座標間距離 


\section{引用文 献}

1）農林水産省生産局生産資材課長通知, 13生産第3988号, 平成 14 年1月10日.

2）http://www.acis.famic.go.jp/youshiki/9_2.pdf/2011年11月 10 日 閲覧

3) U.S.EPA, Pesticide Registration Manual: Chapter 7-Notifications and Minor Formulation Amendments, http://www.epa.gov/ opprd001/registrationmanual/chapter7.html/2011年11月 10 日閲 覧

4) HSE, Data Requirements Handbook, http://www.pesticides.gov. uk/Resources/CRD/Migrated-Resources/Documents/P/physchem. $\mathrm{pdf} / 2011$ 年 11 月 10 日閲覧

5）西澤幸夫, 小倉一雄, 百宏 : 農薬検査所報告 29, 17-22 (1989).

6）西澤幸夫, 廣瀬欣也, 鈴木 修：農薬検査所報告 31, 135-140 (1991).

7）西澤幸夫：農薬検査所報告 32, 21-25 (1992).

8）尾崎幸洋編: 実用分光法シリーズ赤外分光法, アイピーシー出版 部, 1998.
9）佐藤朋覚, 熊谷昌則, 天野敏男, 小川信明: 分析化学 52, 653660 (2003).

10）近藤みゆき:名古屋文理大学紀要 7, 23-28 (2003).

11）橋本 篤, 森 久典, 狩野幹人, 亀岡孝治, 島津秀雄, 小林香 織：照明学会誌93, 501-509 (2009).

12）三木誉史, 徳竹翔太, 石澤広明 : 照明学会誌 94, 436-440 (2010).

13）渡 正博, 尾崎幸洋：分析化学 59, 379-397 (2010).

14) M. Taki, N. Otomo, H. Otani, S. Tomiya, T. Uno and M. Nagai: J. Jpn. Petrol. Inst. 54, 103-107 (2011).

15）日本薬局方, 厚生労働省告示第 111 号（平成 13 年 3 月 30 日).

16）石原 悟, 豊留夏紀, 横山央子, 池長 宙, 斎藤玲奈, 野口雅 美：農薬調查研究報告 1, 24-27(2010).

17）石原 悟, 豊留夏紀：農薬調查研究報告 2, 19-23 (2011).

18）石原 悟, 豊留夏紀：農薬調査研究報告 3, 14-18 (2012).

19）宮下芳勝, 佐々木愼一：ケモメトリックス, 共立出版, 1995.

20）http://www.jaia-aroma.com/MSDS/msds03.pdf/2011年6月 23 日 閲覧

21）山川雅弘, 市岡高男, 早川修二, 山本晃道, 仲 邦熙 : 三重県保 健環境研究所年報 $2,2000$. 